\title{
Observing the stars. Love in the age of systems
}

\author{
Kjetil A. Jakobsen
}

MedieKultur 2010, 49, 26-40

Published by SMID | Society of Media researchers In Denmark | www.smid.dk The online version of this text can be found open access at www.mediekultur.dk

A number of scholars have demonstrated how the cultural industry involves people in a participatory culture in which users actively construct personal identities. However, the link between a public of mass-mediated entertainment and the private sphere of intimacy and personal identity is a paradox. A consistent theory to clarify that paradox is lacking in the cultural studies literature. I suggest that social systems theory in the Luhmannian tradition may explain in economical terms why the continuous performance and intensification of the paradox of mass-mediated intimacy is a major trait of contemporary culture. Nevertheless, the article does not address normative issues. It is neither an apology for the culture industry, nor a condemnation. The aim is simply to bring one of the most powerful tools of analysis in social theory today to bear on an aspect of modern society which is as important as it is baffling.

\section{We are all individuals. Monty Python. Life of Brian - 1979.}

Ever since Gustave Flaubert told the tale of Madame Bovary's addiction to romance literature and her sad quest for self-realisation, Western intellectuals have pondered the fate of personality in the face of the entertainment industries. Many have been pessimistic. Saving the self from the levelling of commercial entertainment was the raison d'être of English pedagogical thought from Matthew Arnold to F.R. Leavis and beyond. In Germany, Max Horkheimer 
and Theodor Adorno took $20^{\text {th }}$ century cultural industry to be an instance of ideological production capable of taking alienation to the point where the alienated no longer feel their alienation, mentally imprinted as they have been with the petty desires and fake understandings of the commercial mass media (Horkheimer \& Adorno, 1969, p. 133). Nightmarishly, the dreamless realism of Hollywood makes the dreamed up idealism of Berkeley and Malebranche come true. Jean C. Baudry similarly compared movie theatres to Plato's cave, where people spend their lives in delusion watching shadows of puppets on the wall (Baudry, 1986). In paragraph 13 of Guy Debords La societé du spectacle from 1967, one reads that the spectacle is "the sun that never sets over the empire of modern passivity" (Debord 1977, 15).

More recently, other voices been heard, notably in the growing field of cultural studies. Inspired by reception history and by the growing interest in the reader and the viewer in literature and film studies, a number of scholars have demonstrated how the cultural industry is a participatory culture involving users in processes of active construction of personhood. Ang on soap operas, Jenkins on fan cultures, and Turkle on games, to name just three, teach this very important lesson (Ang, 1985; Jenkins, 1992, 2006; Turkle, 1984, 1987). The audience members are conceived of as active and knowledgeable producers of meaning, not as products of a structured text (Barker, 2006). According to Fiske (1987), popular culture is a site of semiotic warfare and of popular tactics deployed to evade or resist the meanings produced and inscribed in commodities by the producers.

It remains a fact, however, that the link between a public of mass-mediated entertainment and the private sphere of intimacy and personal identity is a paradox. What seems to be missing in the literature from cultural studies is a consistent theory which can explain in economical terms how this paradox is possible and furthermore why the continuous performance and intensification of this paradox is a major trait of contemporary culture. In this article I will seek to show that social systems theory in the Luhmannian tradition can do precisely this.

\section{What is a medium?}

Social systems theory analyses how binary codes are used to reduce complexity and control contingency, noise and entropy in communication. Examples of such binary codes are pay/ non-pay in economic communications, lawful/non-lawful in legal communications, true/ untrue in science and illness/health in medicine. Medium/form is a primary distinction in systems theory. Observations, whether they be communications (in society) or perceptions (in the psychic system) take place in media. A medium is a relatively stable set of practices enabling communication and/or perception. Within those media, distinctions must be drawn for observations to emerge. Luhmann calls such distinctions forms. Forms are generated in a medium via a coupling of its elements. Media are open-ended couplings of elements, forms are tight couplings. For example, in the medium of the alphabet, written 
words are forms. Examples of media of perception are hearing or sight; examples of media of communication are language, printing or television.

Within the class of media of communication, Luhmann makes an important distinction between media of dissemination and media of success (Erfolgsmedien). The latter are also called media of symbolic generalisation. From the perspective of social evolution, the media of success arose in answer to certain problems caused by the development of new and ever more powerful media of dissemination. They developed as a way to control the incredible insecurity involved in communicating through print media. Such media assure the success of a communication by "clarifying" its intention and placing it within a highly simplified observational field. A coin may have all sorts of culturally specific meanings, but used by the economy as a mode of payment, its meaning is universal. Whether or not alter is really listening to ego and not simply talking is a general problem of communication. But it is a peculiarity of the love/indifference code that the field of observation is limited to whatever concerns the question of whether alter is or is not an attentive observer of the unique individuality of ego. Media of success reduce and control complexity by marking out the observational territory in advance. Thus, scientific communication simplifies the world enormously merely by limiting itself to using the true/false form as observational code. Science "sees" an abbreviated world where it is the nature of everything to be either true or false. Everything that does not concern truth or untruth is pushed out into unmarked space and will in science only appear as noise. Regarding media of success, communication clusters into what Luhmann calls functional systems.

\section{The mass media system}

In the 1990s, Luhmann introduces yet a fourth sense of the word medium, besides media of perception, dissemination and success; that of mass media discourse as an autonomous functional system within society. In mass media discourse, the media of success is information, the observational code is info/non-info.

This theory is presented in a tentative way. The reality of the mass media (Die Realität der Massenmedien), published in book form in 1995, on the basis of lectures given in 1993, seems sketchy and essayistic compared to Luhmann's great works on the economy, law, science and art. The theory of the mass media, which is built into Die Gesellschaft der Gesellschaft from 1997 (but not into earlier Luhmannian renderings of his social theory), seems to differ somewhat from that presented in the earlier work. In The Reality of the Mass Media, Luhmann argues that there are three clearly distinct forms of media discourse: journalism (Nachrichten und Berichte), advertising and entertainment. In Die Gesellschaft der Gesellschaft, only journalism and advertising are mentioned.

Luhmann's proposition for a theory of the mass media system is not up to his usual standards of clarity. But the main reason why it has baffled many commentators is that 
Luhmannian theory already described a society in which technological dissemination of communication is the rule rather than the exception. So why is there a need for a separate theory of the mass media system?

To sharpen the discussion, it is, I think, important to focus on media as a societal system. This is where Luhmannian theory might really make a difference compared to the state of the art in media and communication studies. A societal system is defined by the communicative code that marks out its observational territory. Luhmann also describes two other types of social systems that are not defined by a unique cognitive code. An organisational system, like a union, is defined by membership. An interactional system, like a salon, is defined by place. The media are social universes that engage organisational and interactional systems. This is what is normally analysed in media studies (media sociology, anthropology of media etc.)

In order to understand the point Luhmann is making, one must look closely at the code he proposes. Can the info/non-info code be said to define a societal system within society, and if so, what are the components of this system?

Zurstiege (2005) argues that info/non-info cannot be an exclusive system code since all systems of communication, and not only those of the mass media system, process the distinction between information and non-information. In my opinion, this argument rests on an untenable interpretation of systems theory. As a matter of fact, none of Luhmann's subsystems have cognitive codes that are exclusive in this simple sense. Right or wrong is not just a concern of the legal system, belief or unbelief does not just concern religion. The problems of power are not limited to political communications. It is the auto-reflective use of these distinctions as cognitive code which defines the system. Take the case of science. Truth claims are assumed in all communications. What distinguishes scientific communication from non-scientific is the autoreflexivity and technification of the truth claim. As Karl Popper pointed out many years ago, in scientific communication one does not simply ask whether a communication is true, but also explicitly or at least implicitly whether it is false. Thus claims are made explicit and tested due to the fact of involving not only the plus but also the reflection value of the system.

Science revisits communications, testing the truth value that is otherwise only implied, pushing all that is neither true nor false into unmarked space. Media discourse does something very similar with information. There is a difference between processing information and using info/non-info as a cognitive code. All communication conveys information, but media discourse is alone in conveying only information, seeking at all cost to avoid noninformative language. Only media discourse consistently uses information as a code of second-order observation, (re-)examining everything that happens with regard to whether it is now information or non-information. Thus, an observational territory is marked out where all that is now neither information nor non-information is pushed out into unmarked space. 


\section{What is entertainment?}

How is entertainment to be understood, if we take it to be a programme area within a discourse defined by the observational code of information/non-information? The point of the proposition lies in the peculiar relation of this code to time. What is true or right or profitable today may very well be so tomorrow as well. But what is information today is invariably non-information tomorrow. Every new piece of information is stillborn, turning into non-information the moment it is communicated.

This makes media discourse forgetful, self-destructive and nervously creative. Every new piece of information poses the question: "What now?" Pieces of information may therefore be organised into narrative chains that are driven onwards by suspension as to which information will follow next. This is a favourite strategy of entertainment. In novels and televised entertainment, information is arranged in comprehensive, coherent sequences by being assigned to the "thoughts" and "actions" of a character. "The subject" is a fictitious identity which produces the unity of a narrative, while allowing the observer to negotiate personal identity by trying out the observational frames of "the subject".

Narrative is not the whole truth about entertainment, and Luhmann has been criticised for neglecting other aspects (Laermans, 2005). In fact, there is one more key component in the Luhmannian theory of entertainment. Alongside narrative, Luhmann emphasises the game-like structure of this discourse (Luhmann, 2000b, pp. 51-52). A game is a kind of duplicate reality consisting of episodes with a beginning and an end. By accepting a set of rules - that of chess, football or a social game - one is allowed to step out of reality for a limited period of time. TV-entertainment is a game which one does not play, but observes. Reality is not duplicated by undertaking to act according to certain rules of chess or football, but through the observation of information. Narrative and game join forces. The peculiar relation of the code to time, and the fact that information spends itself the moment it is given, thus demanding new information, are used to build narrative chains of suspense. Furthermore, entertainment tends to use strong sensory and semantic effects in order to attract the attention of psychic systems. Thus the info-code takes the form interesting/boring. Entertainment is programmed to shun boredom, and does so to the point of boredom.

In the digital age, entertainment negotiates new genres in the interfaces between its two historical sources, the game and the fictional narrative. Video games and reality shows have become popular. As pointed out by Sherry Turkle (but not by Luhmann!), online games offer an unparalled opportunity to play with one's identity and to "try out" new ones (Turkle 1984; 1997).

\section{The problem of unity}

Several writers have questioned the choice of info/non-info as the observational code of mass media discourse. Can this code be said to provide organisational coherence to mass media as a whole? Critics claim that Luhmann fails to develop a theory that does justice not 
only to journalism, but also to the discourses of entertainment and advertising (Zurstiege, 2005; Laermanns, 2005; Aguado, 2009). Laermanns (2005) suggests that the observational code of the mass media is not info/non-info, but rather attention/non-attention. "A movie or a pop song, a news report or an Internet site, etcetera, does or does not become a communication that elicits a minimum of public attention" (Laermans 2005, p. 68). Aguado (2009) points out that this involves a misunderstanding, since attention is an operation that takes place in the environment. Being a component of the social system, mass media discourse simply cannot control psychic states like attention, even though it will certainly try to influence them. Aguado suggests instead the somewhat cumbersome alternative of a double observational code of interest/non-interest and relevance/opacity as distinctive of mass media discourse.

I will opt here for what one might call the strong sense of Luhmannian discourse. The auto-reflective use of the info code is seen to demarcate a media system consisting not only of journalism and advertising, but also entertainment. I take it that the three programme areas each derive so many key qualities from sharing an observational code and many interactional and organisational underpinnings that they are best theorised as participating in the same autopoietic processes. Notably they share programme functions.

All systems have programme functions that enable them to select the plus value of the system (in this case information) and to eliminate the reflection value (in this case non-information). On the level of programme function, the most important common denominator among the programme areas journalism, advertising and entertainment is the imperative of dissemination. In order to pass the info/non-info test of the media machine, a communication must be understandable, attractive or spectacular enough to be suited for wide distribution. This basic value allows media discourse to form an extremely strong link with modern politics, which has "democracy" as its leading programme function.

Furthermore, the three forms of mass media discourse converge because they all provide background knowledge about contemporary life and society that "everybody is supposed to know" and which may be taken for granted. Only specialists know the latest developments in science, art or business, but even specialists are expected to be familiar with the latest political event, royal scandal or publicity campaign. Thus the mass media serve to centre a decentred society (Rasmussen, 2003, p. 185). It creates a synchronic time and common frames of reference.

\section{Programme areas and structural links}

There is no denying, however, that the three programme areas perform very different social functions. I propose that we understand mass media discourse as sharply differentiated not on the level of the societal code, but by structural linkage. Journalism "speaks to" politics as "public opinion", advertising "speaks to" consumption and the economy. To what does entertainment "speak"? Luhmann is not very explicit at this point. I suggest we trust 
the findings of all those contemporary researchers in cultural studies and media studies, referred to above. Those findings stress how people use mediated entertainment to experiment with personal identity. According to Luhmannian theory, in modern society personal identities are formed in the system of intimacy (Luhmann, 1982, 1997, pp. 344-347). We should thus look for structural links between entertainment and intimacy.

Intimacy is the discourse of personal as opposed to impersonal relations. One could think that the code of intimacy would be personal/non-personal. That distinction is however universally relevant and would thus be much too impersonal! (Luhmann, 1982, p. 207). Only the love/indifference distinction can orient observation towards the highly personal. In modernity, the love code replaces the family/non-family code which governed the personal domain in pre-modern times. The problem of love is highly personal communication itself, that is, those communications through which an individual seeks to distinguish him or herself from others (Luhmann, 1982, p. 24). Love is the symbolic medium of communication through which alter ego promises to be an attentive observer of the unique individuality of ego. Love is a major ethical category in modernity. But it also has everything to do with modern individualism. Love is where we go seeking to be recognised for the uniqueness of our individuality (Luhmann, 1982, p. 208).

The question now becomes: Is love the major theme of entertainment? This clearly must be answered in the affirmative. Entertainment is concerned, often in an obsessive fashion, with love. Pop songs, fiction, TV shows and films trade in love. There are exceptions, notably in domains which cater to the formation of peculiarly masculine identity. But even in crime stories and war games, love is often a major issue, erotic or as friendship.

Before investigating the link between entertainment and intimacy further, we may note that mass media discourse does exactly what other social systems like the market economy, science or law do. It is a social machine for the reduction and control of self-initiated insecurity, complexity and contingency. Contemporary social reality is so complex that any attempt at representing it would lead to an immediate information overload eliminating any and all perception. Moreover, our world is one of openness and contingency. Nobody knows what will happen tomorrow and there is no way of knowing it. Yet media discourse achieves the incredible feat of manufacturing a "world" in real time, from day to day and minute to minute. Media discourse is simply a non-trivial machine whose chief evolutionary attractor consists of the fact that it accomplishes the paradoxical task of producing a "world" in response to a social reality whose complexity transcends any conceivable set of representations (that is why Luhmann can say that all we - even social scientists - know about the world, we know from mass media discourse (Luhmann, 2000, p. 1))! The machine has at its hand mechanisms for complexity reduction, like the info-code itself, and the capacity for storytelling and the establishment of game-like structures. But notably, media discourse is able to control insecurity and contingency by parasiting the complexity reduction which is already effected by the media of success of other systems. Journalism is concerned with the world of politics and law, with that of the economy or with sports, 
clearly coded areas where the use of symbolic media like power, right, money, property and winning have reduced social complexity greatly. After the primary reduction effected by external media of success, what follows is the secondary reduction effected by the info code itself. Entertainment for its part is largely concerned with observing intimacy. This poses peculiar problems. Entertainment represents a paradoxical public. In this public, it is precisely the private and personal which entertain. The more private and personal a communication is, the greater a public it is likely to reach. Why and how did intimacy become a spectacle?

\title{
Mirroring the self
}

In the four video installations Working Class Hero, King, Queen and Legend, young Berlinbased South African artist Candice Breitz invites a large number of fans to re-perform songs by John Lennon, Michael Jackson, Madonna and Bob Marley, respectively. The filmed karaoke performances are then synthesised and presented together as a choir of individuals, a lonely and yet enthusiastic crowd, singing their souls out in tribute to the media icons of their choice. (Excerpts from the videos may be seen at the artist's web page: http://www. candicebreitz.net.) These works present us with a paradox which is as stark as it is familiar. Fans immersed in the personality of the icon. And yet they are at the same time negotiating unique identities. The imperative of rock/pop culture is "be true to yourself!" And yet it is, if anything, a fan culture. Furthermore, the fans behave in ways which accentuate the paradox. The Lennon fans sing, with great conviction it seems, a song (God from the Plastic Ono album, 1970) with lyrics that simply say that one should not believe in heroes like God or the Beatles.

\author{
I don't believe in kings \\ I don't believe in Elvis \\ I don't believe in Zimmerman \\ I don't believe in Beatles \\ I just believe in me \\ Yoko and me \\ And that's reality
}

One should only trust reality and the only reality, we are told, is "Yoko and me", that is love. But if the Working class heroes of the Lennon installation express distrust in media and mediation, the Queens of the Madonna installation indulge in it. The artist underlines this by giving them each a TV screen to fill. And yet, though lost in mediation, the performances of the Madonna fans come across as freer, more creative and thus more individualistic than that of the Lennon fans.

People observe media icons in order to experiment with the self. From the systems theoretical perspective, these strange tactics for identity formation may be understood as a way 
to handle paradoxes of self-observation. Spontaneous identity formation is a response to complexity. In decentred and rapidly evolving societies, identity may not be granted by tradition, as in the old days when the son of a shoemaker grew up to be a shoemaker. Each individual must be his or her own creator. And personal identity must be recreated every day. In today's complex and rapidly changing environments it must be flexible, dynamic and perhaps even multiple But how do you create your own identity? Obviously through self-observation. But self-observation leads to paradox. A self is the auto-reference of an observational operation. The self is the "I" which observes. It is thus a mode of observation, a view point and a set of scripts for the construction of reality. "I" am how I see. Every such mode is its own blind spot, since I cannot see how I see. Thus only indirect self-observation is possible. Identity formation in modernity is all about handling a double paradox. Firstly, I is eye, secondly I or eye is his or her own creator. The double paradox is dealt with by developing techniques for indirect self-observation.

\section{Side mirrors}

The modern narcissus has a wide range of techniques for indirect self-observation at his or her disposal. I suggest that we divide them into four categories. The first technique defines a whole social system in modernity, that of intimacy. In intimacy, one selects a partner or a close friend, entrusting him or her with observation of oneself. Intimacy is the space of possibilities marked out by the cognitive code of love (Luhmann, 1982).

Secondly, one can construct an observer. This is what television does when it watches Nielsen ratings and what politicians do when they observe opinion polls. In the economy, financial markets have been constructed so that businesses may be observed.

The third possibility for self-observation lies in developing new and more flexible strategies for deparadoxation of discourse, for instance by replacing two value logics by multivalue logics.

The fourth, and one which concerns us here, is indirect self-observation through identification with other people or with the heroes and icons of art and media discourse. Identification enables one to make the observations of a character in a novel, soap opera, song or reality show to be in the world, sensing and gazing and directing sense and gaze like the icon does, thus indirectly testing out the modes of observation that constitute one's own self. Identification allows one indirectly to see oneself from the outside, that is, to observe oneself both as observed and as observer.

Literature enabled $19^{\text {th }}$ century men and women to handle the double paradox that "I" is eye and that "l" or eye is auto-constructed. People read in order to find out who they were and what life and love were about. The novel, the play and the poem offered the possibility of identifying with a character, entering into his or her observational mode, trying out alternative optics for the construction of a social universe. Thus, one was able to make inferences concerning the nature of one's own observational modes (Luhmann, 2000a, p. 93). 
Those modes would otherwise have remained invisible to the observer himself. However, ever since art's breakthrough to full autonomy in the second half of the $19^{\text {th }}$ century, it has offloaded the function of self-observation and thus identity formation to the mass media, notably to electronic media like television and film. Art is still concerned with identity, but on a level of the third- and fourth-order observer, observing the contingency of identity formation in other social contexts, notably that of the mass media. This is, of course, precisely what Breitz does, but it is not a new phenomena. Flaubert's Madame Bovary is often called the first modern novel. It is a novel that observes the role of the popular romance in feminine identity formation. The tragedy of Madame Bovary is that she has read too many romances.

\title{
The love code
}

Pop songs are almost always about love, as are many films and TV shows. If art is a parasitical observer of entertainment and other forms of media discourse, then entertainment is itself a parasitical observer of the original terrain of identity formation in modernity. In modernity, people find out who they are by engaging in love communications. Love is thus the primary solution to the problem of self-observation. It is the medium of success by which alter promises to be an attentive observer of the unique individuality of ego. One undresses, but only to the gaze that promises to observe individuality attentively. The opposite of love is not hate but indifference. In the system of intimacy communications that are neither loving nor indifferent will fall in unmarked space and appear as noise (but they may very well be picked up as communications by other systems). In Breitz's work Legend, we see the incredible spectacle of disfavoured people from African slums proclaiming their fervent belief in Western individualism guaranteed by the success medium of love:

\author{
Could you be loved and be loved? \\ Don't let them fool ya, \\ Or even try to school ya! Oh, no! \\ We've got a mind of our own, \\ So go to hell if what you're thinking is not right! \\ Love would never leave us alone, \\ A-yin the darkness there must come out to light. \\ Could you be loved and be loved? \\ Could you be loved, wo now! - and be loved? \\ Don't let them change ya, oh! a \\ Or even rearrange ya! Oh, no!
}

In intimacy, one tries out identity against the mirror of an observer who through the symbolic medium of love, claims to be as interested in me as in himself. I am eye, but who am eye? You, my lover, will tell me! The mass media talk and sing of love, thus parasiting this 
discourse of identity building. Yet only a few celebrities are able to form their personal identity by observing how they are observed in the media. What "the man in the street" must do is to identify with heroes and icons. For him, identification with media characters is a key to the construction of self. He moves his body like Michael Jackson. He feels the emotional loss of John Lennon (Mother you left me, but I never left you). He speaks up like Bob Marley. He directs the incoming gaze like Madonna does. Identification allows him to see the world from the point of view of the icon, thus testing out new ways of apprehending the world. Art work, like Queens and Working class heroes, lets us observe how entertainment provides the spectator with the means to observe himself indirectly and freely, without obligation, by trying out alternative modes of observation.

Entertainment's fixation on love may seem strange knowing the complexity, richness and mystery of human life. What explains this emotional monomania is simply that the love/indifference code is the only one which is able to reduce the complexity of personal life on a steady and predictable basis, while at the same time addressing the essential issue of private life, that of personal identity. True, entertainment is not always intimate. It also parasites other codes like the win/lose code of sports, games and war. The lawful/ non-lawful code of the legal system is remediated in crime stories. Crime, sports, games and war may be mixed with love in various combinations. Still, entertainment needs love in order to communicate securely and universally while inciting the attention of human psychic systems.

\section{Love in the age of "reality"}

In The Reality of the Mass Media, Luhmann noted that the fictional narrative, a form which the electronic media inherited from the novel, was being supplemented by new forms of "non-fictional" entertainment. He noted the importance of talk shows in which one was able to observe the private life and nature of people with non-fictional identities (Luhmann, 2000b, pp. 60-61). Here, Luhmann, who supposedly did not have an eye for popular entertainment, showed surprising clairvoyance. Since the publication of his book on media discourse in 1995, so called "reality shows" have grown to become the major trait of popular entertainment, both on TV and online. In art and literature, fiction is also thought to be declining as new forms of reality production arise (e.g., Foster, 1996; Behrendt, 2006; Shields, 2010). How may we understand these developments?

We have seen how entertainment and literature allow identity formation through second-order observation of other people's identities. In reality shows and talk shows, such observations may carry on without reality loss. The spectator observes how other people think and talk and what they are like in their intimacy, what they do and do not perceive, notably how nontransparent they are to themselves. Thus, she can try on alternative identities, and all that without reality loss and without obligation to defend those identities when reality sets in. 
From the Luhmannian perspective, the rise of "non-fictional" forms of entertainment is proof of the increasing autopoiesis and self-referential closure of media discourse. In the early days of TV, the medium would draw its content from other systems, supplying a stage to politicians and to actors and writers from the art system. Today the media system seems capable of consecrating everybody and anyone as a "star", instantly. What entertainment does in the post-fictional age is typically simply to structure the "real" intimacy of a group of people as a game and then let the camera observe the unfolding of this intimacy.

\section{Mass media or my media?}

In proposing a new theory of the mass media, Luhmann is somewhat out of pace with developments in media and communication studies, where many have argued that broadcasting and thus mass media are being replaced by interactive and multilinear communication (e.g., Benkler, 2006, chapter 7; Bohman, 2004; Castells, 1996).

There is certainly no reason to downplay the importance of social media and new forms of interaction in digitised broadcasting. But it seems unlikely that such developments will make the Luhmannian perspective obsolete. Remember that we are discussing a societal system, not an interactional one. Even if there is interaction between alter and ego, a media machine may be at work which uses its peculiar cognitive code to mark out an observational territory. The Internet changes broadcasting, but it does not mean the end of media industries and thus of media systemic communication. Unsurprisingly, it is perfectly possible to adjust Luhmann's social cybernetics to the specific needs of a theory of cybermedia (e.g., Qvortrup, 2003; Baeker, 2007).

To avoid misunderstanding, it is perhaps essential to stress once again how different the Luhmannian theory of mass media is from the determinist theories in the traditions of critical theory or French structuralism. Luhmann's communication theory is a theory of non-communication, or to put it more moderately, a metareflection on how institutions and people deal with the unavoidable insecurity and complexity of communication. Society and psychic systems are described as independent unities, self-referentially closed in their autopoiesis. Thus, the social system does not determine in a straightforward way the acts and understanding of individuals, these are other to the system. As a commentator aptly summarises: "How social or psychic systems actually deal with mass communications is literally their own affair" (Laermanns 2005, 64).

Drawing on this perspective, I would argue that the overwhelming success of media discourse as a functional system in modernity is precisely a result of the freedom it endows on the consumer. The Reality of the Mass Media is dynamic and flexible, subject to no consensual claims. The semi-fictional world of journalism, advertising and entertainment convinces because it makes each of its consumers the centre of his or hers own universe, allowing individuals to employ communications at their will in relentless and open-ended construction of personal identity. The shadowy staging of a world of information succeeds 
precisely because media consumers do not relate to it the way prisoners in Plato's cave do. We do not receive the images passively. We trust "the reality of the mass media" because you and I have made it into our own. We appropriate journalism and advertising like the Queens appropriate Madonna, with creativity and irony. It is true, as Christina Spurgeon, has noted, that we are undergoing a shift from mass media to my media (Spurgeon, 2008). But precisely in order to grasp the nature of that shift, we should not forget the ways in which the mass media were also always my media.

\section{A double contingency}

Entertainment is obsessed with intimacy. There is a price to pay for this and that is repetition. The observational space of intimacy must to be marked out in every single communication and on the inside of the already narrowed observational space of the info code. As media discourse observes intimacy, a famous paradox arises. In intimacy, the difference between noise and communication is marked by the form love/indifference/unmarked space. But can media discourse observe love? Unfortunately it cannot. Media discourse does not have time to observe anyone or anything attentively. The time structuring of the two systems is irreconcilable. What is love today may very well be so tomorrow; the promise of a shared future is indeed at the heart of love. But what is information today invariably turns into non-information tomorrow. If media discourse had its way, people would divorce every day. Worse still, entertainment cannot thematise those uneasy and opaque interfaces of communication with the mind and the body which are the leitmotif of love communications. Entertainment talks in clichés, headlines and abbreviations, with little sensibility for that unique individuality which love promises to observe. So entertainment, a major segment of media discourse, one of the most important social systems in modernity, specialises in observing precisely what it cannot observe: Intimacy. This is undoubtedly one of the weirdest traits of contemporary society and a continuous source of frustration and amusement to art. Also, it is a source of irritation to modern men and women. From the perspective of love, media discourse is noise. And yet intimacy needs the side mirror of entertainment. What we have here is a relation of double contingency. Extremely dissimilar discourses observe each other and respond to each other. In double contingency, A's action depends on what B does, while B's action depends on what A does. Entertainment responds to intimacy, intimacy to entertainment. They observe each other mutually and the insecurity of inferences is bottomless. However, cybernetic theory shows, in mathematical terms, that relations of double contingency tend to integrate better and offer more stability than those of simple contingency.

We should thus expect the liaison of entertainment and intimacy to intensify, providing either that the autopoiesis of media discourse deepens or that the importance of individualism in personal life continues to grow. The spectacle of intimacy will not go away. 


\section{Conclusion}

Various writers have questioned whether the info code provides coherence to the whole of mass media discourse or whether Luhmann puts too much emphasis on journalism to the detriment of entertainment and advertising. I have reviewed these arguments in brief, while seeking to clarify the Luhmannian theory of entertainment. I argued that the contrasts between the three programme areas of media discourse may be explained by the fact that they link up with very different discourses; news with politics, advertising with the economy and entertainment with intimacy. In reference to the work of the pop artist Candice Breitz, I sought to describe some key traits of the structural linkage between entertainment (a programme area in media discourse) and intimacy (an altogether different social system, geared towards the spontaneous formation of personal identity in the symbolic medium of love). The structural linkage is found to be one of double contingency, wherein entertainment responds to intimacy while personal identity is formed observing media entertainment. The bind is thus very strong, but it is also the source of much irritation, since the social logics of the two discourses are so dissimilar.

Finally, we may note that even if art is no longer a medium of identity formation, having offloaded that function to entertainment, a secret link between art and love persists. This is because art and love are, from the logical point of view, opposites, and thus complementary. In a love communication, alter claims to be a singularly attentive observer of the unique individuality of ego. In an artistic communication, alter claims to be worthy of singularly attentive observation. In art, ego observes the actions of alter, in love alter observes the actions of ego. When a communication rather than a human being is observed through the medium of love, we call that communication a work of art.

\section{References}

Aguado, J. M. (2009). Self-observation, self-reference and operational coupling in social systems: Steps towards a coherent epistemology of mass media. Empedocles. European Journal for the philosophy of communication. Volume 1, nr 1, 59-74.

Ang, I. (1985). Watching Dallas. Soap operas and the melodramatic. London: Metheun.

Baeker, D. (2007). Studien zur nächsten Gesellschaft. Frankfurt: Suhrkamp.

Baudry, Jean-Louis (1986) Ideological Effects of the Basic Cinematographic Apparatus. In Phillip Rosen (ed.). Narrative, apparatus, ideology (pp. 286-298) New York: Colombia Press.

Barker, C. (2003). Cultural studies. Theory and practice. London: Thousand Oaks.

Behrendt, P. (2006). Dobbeltkontrakten - en cestetisk nydannelse. København: Gyldendal.

Benkler, Y. (2006). The wealth of Networks. How Social Production Transforms Markets and Freedom. New Haven, London: Yale University Press.

Bohman, J. (2004). Expanding dialogue: The internet, the public sphere and prospects for transnational democracy. In N. Crossley \& J. M. Roberts (Eds.) After Habermas: New perspectives on the public sphere (pp. 131-155). Oxford, Malden: Blackwell Publishers.

Castell, M. (1996). The Information Age: Economy, Society, and Culture, Volume 1: The Rise of the Network Society, Oxford, Malden, MA: Blackwell Publishers. 
Debord, G. (1977). The society of the spectacle. Translated from the French by D. Nicholsen-Smith. Detroit: Black \& Red.

Eisenstein, E. L. (2005). The printing revolution in early modern Europe (2nd edition ed.). Cambridge UK: Cambridge University Press.

Fiske, J. (1987). Television culture. London: Methuen.

Horkheimer, M \& Adorno, T.W. (1969) [1944]. Dialektik der Aufklärung. Philosophische Fragmente. Frankfurt: S.Fischer Verlag.

Jenkins, H. (1992). Textual poachers. Television fans and participatory culture. New York: Routledge.

Jenkins, H. (2006). Fans, bloggers and games. Exploring participatory culture. New York: N.Y. University press. Kittler, F. A. (1985). Aufschreibesysteme: 1800/1900. München: Wilhelm Fink.

Laermans, R. (2005). Mass Media in Contemporary Society: A Critical Appraisal of Niklas Luhmann's Systems View. Cybernetics and Human Knowledge, 12(4), 51-70.

Luhmann, N. (1982). Liebe als Passion, Frankfurt: Suhrkamp.

Luhmann, N. (1995). Social systems, Stanford: Stanford U.P. Translated by Bednarz og Baeker [Soziale Systeme. Grundriss einer allgemeinen Theorie 1984].

Luhmann, N. (1997). Die Gesellschaft der Gesellschaft (2. Aufl.). Frankfurt: Suhrkamp.

Luhmann, N. (1998). Observing modernity, Stanford: Stanford U.P. Translated by W. Whobrey [Beobachtung der Moderne 1989].

Luhmann, N. (2000a). Art as a social system. Stanford: Stanford U.P. Translated by E. M. Knodt. [Die Kunst der Gesellschaft 1995].

Luhmann, N. (2000b). The reality of the mass media, Cambridge: Polity press. Translated by K. Cross. [Die Realität der Massenmedien 1995].

Luhmann, N. (2004). Warum haben Sie keinen Fernseher, Herr Luhmann: Letzte Gespräche mit Niklas Luhmann (Wolfgang Hagen ed). Berlin: Kulturverl. Kadmos.

Luhmann, N. (2008). Schriften zu Kunst und Literatur, Frankfurt: Suhrkamp.

Qvortrup, L. (2003). The hypercomplex society. New York-Berlin: Peter Lang publishers.

Rasmussen, T. (2003). Luhmann. Kommunikasjon, medier, samfunn, Bergen : Fagbokforl.

Serres, M. (1980). Le Parasite. Paris: Grasset.

Shields, D. (2010). Reality hunger : a manifesto. London: Hamish Hamilton.

Spurgeon, C. L. (2008). Advertising and New Media. New York, NY: Routledge.

Turkle, S. (1984). The second self: Computers and the human spirit. New York: Simon \& Schuster.

Turkle, S. (1997). "Constructions and Reconstructions of Self in Virtual Reality: Playing in the MUDs." In S. Kiesler (ed.) Culture of the Internet. Mahwah, New Jersey: Lawrence Erlbaum publishers.

Zurstiege, G. (2005). "Kleiner Grenzverkehr zwischen Werbung, Journalismus und Kunst - für Siegfried J. Schmidt zum 60. Geburtstag." http://www.sjschmidt.net/essays/texte/zurst1.htm

Kjetil A. Jakobsen

Associate professor, Ph.D.

Department of philosophy, classics, history of art and ideas

University of Oslo, Norway

k.a.jakobsen@ifikk.uio.no 